\title{
COMMUNAL POLITICS IN MALAYSIAN BORNEO
}

\author{
G. Paul Bradley \\ University of Michigan, Flint College
}

$\mathrm{T}$

HE ENTRY of the peoples of British Borneo into an era of mass politics has been swift, almost entirely compressed in the early years of the 1960's. Certain fortuitous factors intervened to accelerate what originally promised to be a slow-paced process. These were chiefly: (1) the advocacy in May 1961 of an enlarged Federation of Malaysia by the Prime Minister of Malaya, Tunku Abdul Rahman, offering the option of independence by adherence to an established state; (2) the surprising momentum which the Malaysian proposal acquired between 1961-63, partly due to its firm support by British colonial officials in Borneo; and (3) the availability of existent Malayan political forms, particularly the Alliance concept of communally based political parties joined together in a governing coalition, which proved transferable to the similarly multi-racial society in Borneo.

The rapid pace of this change was the more noteworthy, since the antecedent colonial tradition had been strongly authoritarian. Until World War II Sarawak had been for over a century the personal preserve of James Brooke, the "White Rajah," and his heirs; North Borneo, known since 1963 as Sabah, had since 1881 represented the last of a dying species, the chartered commercial company. ${ }^{1}$ After the war both had become Crown Colonies with a British governor wielding all significant executive authority. Legislative councils with initially limited powers and restricted electorates were gradually becoming partially popular bodies. Yet within a period of less than three years, a complex multi-party system emerged in both territories, functioning by 1963 with the full accouterments of parliamentary democracy. This article will appraise (1) the major features of the evolving Bornean party system between 1961-63, and (2) the crucial problem of cabinet instability under communal coalitions in Borneo since the formation of Malaysia in $1963 .{ }^{2}$

\section{Background Fagtors in Bornean Politigs}

Race is indisputably the root element in present-day Bornean politics. The ethnic diversity of both Sarawak and Sabah is almost bewilderingly complex. The crucial distinctions lie between (1) the indigenous pagan inhabitants, a minority converted to Christianity by Western missionaries; (2) the Muslim Malays and Islamized indigenes, sometimes known as "para-Malays"; and (3) the immigrant Ghinese. Technically the first two categories are deemed Native and enjoy a privi-

\footnotetext{
${ }^{1}$ The third state in British Borneo, the tiny oil-rich Sultanate of Brunei, chose not to join Malaysia in 1963; hence political developments there are considered only as they impinge on Sarawak and Sabah. Brunei once ruled over a large Bornean kingdom, reaching its culmination in the sixteenth century. The rule of its Malay Sultans had become especially oppressive when James Brooke entered the Bornean scene.

${ }^{2}$ The author has taken two field trips to Malaysia, first in the spring of 1963, again in the summer of 1965 , the latter made possible by a research grant from the University of Michigan Horace H. Rackham School of Graduate Studies. Acknowledgement is made of the use of the Sarawak Museum library in Kuching, a valuable depository of public records and regional newspapers.
} 
leged constitutional status. ${ }^{3}$ Although most Bornean Chinese are now local-born, they remain largely an alien element whose ultimate loyalty is ambivalent, part Bornean, part homeland China, and in varying degrees for different sections of the Chinese community.

To a significant degree the non-Malay indigenes in the two Bornean states have a distinctive racial background. ${ }^{4}$ In Sarawak the Ibans are the largest indigenous group, accounting for nearly a third of the total population of roughly 800,000 persons. In Sabah the Kadazans, previously known as Dusuns, are numerically the most important of the indigenes, having nearly one-third of the approximately halfmillion inhabitants. With certain exceptions the non-Muslim indigenes are interior peoples who practice shifting dry-rice cultivation. The Sarawakian Ibans continue to maintain their traditional long-house communities, the Kadazans in Sabah decreasingly so.

A small number of the interior peoples has adopted cash-crop agriculture, mostly in rubber and pepper small-holdings, the latter an important feature of the economy in Sarawak. Some of the smaller indigenous groups, like the Kayans, Kenyahs and Kelabits in Sarawak, are related to much larger groups in Indonesian Borneo but without active intercommunication.

Most Malays and Islamized indigenes live in coastal villages, engage in fishing, wet-rice cultivation, and the growing of sago. There are, however, numerous Malay settlements of small traders and farmers in the interior. In Sarawak Malays filled subordinate administrative posts under the Brooke dynasty and constituted a native elite. The Malays are a numerically important minority of about 18 per cent in Sarawak, less numerous in Sabah.

Other important Muslim groups include the Melanaus in Sarawak and the Bajaus in Sabah. The latter's ancestors were fierce pirates who infested local waters until the mid-nineteenth century; today they specialize in cattle-raising and are known as skilled horsemen. Practitioners of Islam appear to have a considerably higher status than non-Muslims, due partly to the prestige of the ancient Brunei Sultanate, the original source of Muslim culture in Borneo.

Large-scale Chinese immigration was systematically encouraged by the British to facilitate the economic exploitation of Borneo. In Sarawak the Chinese now constitute approximately one-third of the total population, in Sabah nearly a fourth. In the two states combined, they are, significantly, the largest single racial group. Now regarded as permanent settlers, the Chinese are local-born to an increasing degree - 80 per cent in Sarawak, 77 per cent in Sabah. Like Malayan Chinese, they dominate the non-European economy. Concentrated chiefly but not exclusively in urban areas, they penetrate nearly every sector of the economy, including trade, market gardening, timber concessions and export businesses.

\footnotetext{
${ }^{3}$ Actually Malays were originally migrants, as they continue to be to a lesser extent, from Malaya, Indonesia and Brunei. Certain ethnic specialists employ the term "para-Malay" to describe pagan indigenes that adopt a Malay style of living and embrace Islam.

4 The 1960 Government census reports for the two states are valuable sources of a wide range of statistical information. Both reports were conducted by L. W. Jones, Superintendent of Census for both territories, and were separately published in 1962. Also useful as sources of general information are the Annual Reports for Sarawak and North Borneo, published by the colonial administration until 1963 .
} 
As elsewhere in Southeast Asia, the Chinese in Borneo devoted intensive efforts to establishing their own China-oriented schools, and now enjoy a marked educational advantage over the indigenes. Typically, ten times as many Bornean Chinese youth complete secondary education as those of the indigenous peoples. In the early 1960's Sarawakian Chinese attained a 53 per cent rate of literacy compared to the indigenous rate of 13 per cent; in Sabah, the Chinese were 54 per cent literate, the indigenes, 17. In the postwar period the Chinese secondary schools in Sarawak were an important stimulus for radically inclined Chinese youth, some of whom were attracted to the developing Communist organization there.

Each year the small populations in the two states undergo a 3-3.5 per cent increase. They have a strikingly youthful composition, over 40 per cent of the total population being under 15 years of age; over half the Chinese segment is in this category. Significantly the Chinese minorities in both Sarawak and Sabah grow proportionately faster than the indigenous groups. For example, between 1947 and 1960 the Sarawakian Chinese increased by 57.9 per cent compared to the 28.3 per cent of the indigenes, the Chinese death rate being considerably lower.

Two distinct levels of racial tension are present in these multi-racial societies. Frictions exist between the local Malays and non-Muslim indigenes. In Sarawak they are heightened by the supercilious attitude toward the "natives" that prevails among the Malays, as a one-time privileged caste under the Brookes. Both groups, however, are fearful of the ever-expanding economic power of the Chinese and their anticipated numerical preponderance, especially in Sarawak.

Not all social tensions in Borneo can be attributed to ethnic divisions. A degree of conventional class antagonism arises between employers and workers, especially as projected by the developing trade union movement in Kuching. Among the Chinese the use of various dialects, deriving from their diverse places of origin in China, is divisive. In Sarawak, for example, seven Chinese dialects are employed. As among Singapore Chinese, a wide gap exists between the Chinese educated in English-language schools and graduates of Chinese-language schools. In Sabah a minority of Chinese has intermarried with local Kadazans, and appears well assimilated in Kadazan areas of rural Sabah, an interesting deviation from the norm of Chinese clannishness.

The economies of Sarawak and Sabah largely conform to the classical pattern of developing states: (1) concentration on a small number of primary products; (2) domination of foreign trade by a few key exports; (3) periodic fluctuation in the market price of these exports, constituting an element of chronic instability in their economies; (4) heavy reliance of government revenues on export duties, also variable from year to year; and (5) a critical dependence on certain imports, especially foodstuffs. ${ }^{5}$

Nearly 40 per cent of the Sarawakian economy is devoted to export production, principally rubber, timber, and pepper. Most of these products are shipped

\footnotetext{
"Recent economic data on the Bornean states can be obtained from their respective State Development Plans as follows: (1) Sarawak Development Plan 1964-68, Kuching, 1963; (2) Sabah Development Plan 1965-70, State of Sabah, Malaysia. Both were designed to be incorporated into a larger Malaysian Development Plan, announced in 1966.
} 
to the entrepôt port of Singapore for wider distribution. Of secondary importance is the oil refinery maintained in Sarawak by Brunei oil producers.

The economy of Sabah is at present highly bouyant. Following the destructive hiatus of the Japanese occupation, the economy enjoyed a remarkable boom in the 1950's, especially in the expanding timber industry. Its less favorable concomitants have been a severe inflation and a chronic labor shortage. Interestingly, Japan has become the leading purchaser of Sabahan exports, absorbing nearly half of the total and recently 80 per cent of timber exports. Rubber and copra are also important exports. Sabah's foreign trade is oriented toward Hong Kong and the Far East rather than Singapore.

In both states the working population is overwhelmingly engaged in agricultural production - over three quarters in Sarawak, about 80 per cent in Sabah. Large numbers are engaged in padi production, rice being the preferred staple food. Neither state being self-sufficient in rice production, imports are required to fill about a third of total domestic requirements.

Bornean systems of communication remain primitive. Sarawak's few roads are found mostly in such urban centers as Kuching and Sibu; river transportation remains vitally important for the interior peoples. In Sabah the important trade centers on the West and East Coasts as yet have no overland link, although tortuously slow progress is reported on a connecting road. The operations of the single railroad on the West Coast are hampered by intermittent landslides. Obviously the paucity of communications delays a development of a statewide political consciousness transcending established ethnic loyalties.

\section{The Formative Phase (1961-63)}

Prior to 1961 political stirrings were largely confined to Sarawak. The Federation of Malaya had become independent in 1957. Singapore acquired internal self-government in 1959. Indonesia had been politically activist for the whole postwar period. But Sarawak remained a political backwater.

The Sarawak constitution, promulgated in 1956 after four years of dilatory preparation, marked a modest advance toward wider local participation in government. Several of its features require comment. ${ }^{6}$ For the first time the so-called Unofficials held a legislative majority in the Council Negri, with 24 representatives in a 45-man body. Rather than owing their seats to the governor's nomination, they were now elected under a complicated three-tier election system. Only at the local level did a restricted number of voters choose the members of District Advisory Councils. From their own numbers the District Councillors then elected the members of five Divisional Advisory Councils, the Divisions comprising the Colony's principal administrative units. Finally the Divisional Councillors, joining those of urban Councils in Kuching, Sibu and Miri, selected the 24 Unofficials (later raised to 36) of the Council Negri from their own ranks. The element of popular participation was small, since only rate-paying householders could vote in District elec-

\footnotetext{
${ }^{6}$ The constitutional summation in the tome edited by L. A. Sheridan, Malaya and Singapore -The Borneo Territories: The Development of the Laws and Constitutions (London: Stevens, 1961), is legalistic. A more realistic analysis is found in Liang Kim Bang, Sarawak; 1941-57, No. 5 in the University of Singapore's "Studies on Borneo and Malaya," 1964, pp. 19-21.
} 
tions. In Sabah the nominated element in its Legislative Council persisted until the eve of Sabah's adherence to Malaysia. ${ }^{7}$ Belatedly in 1963, an indirect election system similar to Sarawak's was introduced in Sabah. ${ }^{8}$

The original Cession decision in 1946 marks the beginning of popular political controversy in Sarawak. In the view of the last White Rajah, Charles Vyner Brooke, the financial burden of reconstruction and modernization in war-torn Sarawak would be onerous. An ancillary influence on the Rajah's judgment was his known distrust of his presumptive heir, Anthony Brooke. He proceeded to negotiate the transfer of his family dominion to Colonial Office administration, precipitating a bitter dispute in Sarawak. Many Malays and Ibans opposed Cession, and favored the retention of a regime whose beneficiaries they had been. ${ }^{9}$ An influential Malay faction, enjoying the support of the prestigious Datu Bandar, and also the Chinese supported Cession. Under the Colonial Office the Chinese anticipated more equitable treatment and an expansion of trade contacts with Chinese Singapore and Hong Kong, also Crown Colonies.

To advance the anti-Cession cause, its Malay leadership made effective use of an existent Malay National Union, organized in 1939 for primarily social purposes. The principal argument this group advanced was that Sarawak already enjoyed the equivalent of independence under the personal rule of the Rajah, and accepting Colonial Office tutelage would constitute a step backward; its validity was dubious, for Sarawak had been under formal British protection since 1888. To protest the advent of Colonial Office control, many Malay bureaucrats resigned. In December 1949 the agitation came to a climax with the assassination of the British Governor by a Malay extremist. Even after this conflict receded, friction between the opposing Malay factions persisted, and in the early 1960's they formed two rival parties.

After the war the Sarawakian Chinese were politically in a transitional stage. Before 1941 the Government tended to consider the Chinese community a separate, largely autonomous entity. The system of Kapitan Chinas with quasi-official authority had been devised to maintain limited contact between the Government and the Chinese. Its rationale was that no European administrator (or Malay subordinate) could understand the complexities of Chinese society. Skill in acquiring material goods became the principal criterion for selecting the Kapitans. During the war they acquired an unsavory reputation for collaboration with the Japanese Occupation, so that in the eyes of the Chinese, the old system of indirect control became thoroughly discredited. Many Chinese, especially the students in Chinese

\footnotetext{
${ }^{3}$ Nominated elements in Bornean legislatures, which were designed to represent various corporate bodies and ethnic groups, helped to sustain communal divisions.

${ }^{8}$ Sabah Annual Report 1963 (State of Sabah: Government Printer, 1964), pp. 217-20. Sabah had four Residencies, the middle tier in its electoral system, which were the equivalent of the 5 Divisions in Sarawak. A system of Local Authorities had been gradually expanding in Sabah since 1952. Information regarding postwar political developments in Sabah is found in M. H. Baker's North Borneo, The First Ten Years, $1946-$ 1956, No. 1 in the Singapore "Studies on Borneo and Malaya," Singapore, 1962. An impressionistic account of postwar changes is given in the well-written Corona Library volume on North Borneo by K. G. Tregonning (London: H.M.S.O., 1960).

'Liang's interpretation of the Anti-Cession Movement is that a long-privileged governing class (the Malays) was engaged in an act of political self-preservation, op. cit., pp. 5-13.
} 
schools, began an active search for fresh leadership, more in tune with postwar Asian political trends. An increasing number turned to affiliation with the extreme Left.

In this fluid atmosphere there appeared in 1959 the first well-organized political party, the Sarawak United People's party (SUPP). The party's major objectives were attaining Sarawak's independence, a system of parliamentary democracy, and ill-defined socialism. Pledged to the fostering of racial harmony in Sarawak and self consciously multi-racial in its membership recruitment, SUPP was predominantly a Chinese party, although initially attracting considerable support from non-Malay indigenous groups, particularly Ibans. In SUPP branches, the key post of secretary was often held by a Chinese with an indigene serving as chairman. ${ }^{30}$ Significantly, SUPP led the protest of the Chinese community against Government's policy of requiring the use of English in all Government-aided schools.

Articulation of SUPP's program was dominated by its two principal leaders, Ong Kee Hui and Stephen K. T. Yong. Ong, whose grandfather was the ranking Kapitan China under the last Rajah Brooke, was a prominent banker, leading member of the Kuching Municipal Council, a thoroughly bourgeois political leader; Yong, an articulate Chinese lawyer. While Yong appears to hold views slightly to the left of Ong, both are moderates, who stressed constitutional means of attaining the party's goals.

A moderate-radical cleavage developed in SUPP, strikingly similar to the earlier factional split in the People's Action party in Singapore. ${ }^{11}$ SUPP's pro-Communist, radical faction, led by certain trade unionists in Kuching, acquired wide influence in SUPP branches. The colonial Administration believed SUPP to be subject to continuous infiltration by the "Clandestine Communist Organization" (CCO), a label devised by the Special Branch of the police to cover the Communist movement's manifold activities. ${ }^{12}$

As a counter to SUPP, a second political party was formed in early 1960 , the Party Negara Sarawak (PANAS).$^{13}$ Originally the party attracted multi-racial support, including prominent leaders from both Malay and Iban communities. The

${ }^{10}$ See Michael B. Leigh, The Chinese Community of Sarawak: A Study of Communal Relations, No. 6 in Singapore "Studies on Malaysia," Singapore, 1964. Leigh reports that in 1962 all but three of 16 SUPP branches had native chairmen.

${ }^{11}$ See the author's appraisal, "Leftist Fissures in Singapore Politics," Western Political Quarterly, 18 (June 1965, Part 1), 292-308. As in PAP, English-educated Chinese were prominent in SUPP's moderate faction; Chinese-educated Chinese in the radical wing.

${ }^{12}$ See the Government's White Paper, The Danger Within: A History of the Clandestine Communist Organization in Sarawak (1963). It traces the development of the local Communist movement from its obscure origins as the "Sarawak Anti-Fascist League" during World War II. Considerable attention is given a captured CCO document, which purportedly established the party line on collaboration with SUPP. According to the directive, "our party - the Sarawak United People's Party — embraces all races. Though led by the propertied class, we can still make use of them at the present stage.... We should make use of these prominent figures to deceive the British imperialists, preventing them from perceiving the true face of our party. ... We should make use of it when it is useful and attack it when it becomes useless." The Danger Within, p. 28. The import of the White Paper was to portray SUPP as little more than a Communist "front" organization. This analysis distorts the gravity of the internal conflict in SUPP and the staying power of the moderate leadership.

${ }^{13}$ PANAS' chairman, the Datu Bandar, later acknowledged that his party was deliberately formed to oppose SUPP, "Sarawak by the Week," Government Information Service, No. $17 / 63$. 
Datu Bandar, Abang Haji Mustapha, however, assumed the dominant leadership role, and PANAS subsequently became the vehicle of the Cessionist Malay faction.

Prior to 1961 widely divergent groups advanced tentative proposals for unification of British Borneo. In 1958 British colonial officials initiated wide discussions of a Closer Association project, enabling its two Bornean territories and protectorate of Brunei to advance toward self-government under common institutions. Its advocates stressed certain positive integrative elements. The area shared a common lingua franca in Malay and a common currency. A degree of economic complementarity between Brunei and Sarawak derived from the processing and re-shipment of Brunei oil in Sarawak. A large number of administrative officials in Brunei was trained in Sarawak. All three states had been under British protection since 1888. But their conflicts of interest proved controlling. Brunei was reluctant to share its rich oil revenues with its two poorer neighbors. Sabah, free of serious internal subversion, was alarmed by the growing CCO influence in Sarawak. In both Sarawak and Sabah the non-Muslim indigenes feared the numerically strengthened position which both Malays and Chinese would enjoy in a Bornean federation.

A radically different formulation was voiced by A. M. Azahari, the volatile nationalist leader in Brunei, whose Party Ra'ayat, formed in the late 1950's, had won wide popular response. In 1959 the Sultan of Brunei had taken the first hesitant step to move his feudal state toward representative government. A constitution was instituted, which established a Legislative Council, 16 of whose 33 members were to be elected. ${ }^{14}$ The Party Ra'ayat subsequently won easy control of all 16 seats. Azahari's ambition was to restore Brunei's ancient grandeur and reabsorb its former territories. As a first step he called for the return of adjacent Limbang district in Sarawak, the last Brunei territory to be annexed by the White Rajahs. Interestingly, the advocacy of a Bornean federation was a doctrinal point of coincidence between the Party Ra'ayat and SUPP. For Azahari, the overtones were strongly Malay; ${ }^{15}$ SUPP envisioned an interracial union.

The Malaysian proposal in 1961 provided the main impetus for a whole array of new political parties in both Sarawak and Sabah and their integration into a parliamentary system. The intricate relationship between the Federation of Malaya and Singapore, whose independence was imminent, formed the essential background for Tunku Abdul Rahman's suggestion. ${ }^{16}$

In 1961 the pro-Communist radical faction in the Singapore PAP threatened to take over the party, although the moderates under Lee Kuan Yew still controlled the Government. The conservative, Malay-dominated Alliance Government of Malaya faced the unpalatable prospect of an extreme leftist cabal governing independent Singapore. Alarmist analogies with Castro's Cuba were precipitately

\footnotetext{
${ }^{14}$ Sheridan, op. cit., pp. 120-23. Contemporaneously Brunei made a new treaty arrangement with Britain, under which a High Commissioner would replace the former British Resident, and Britain retained control over Brunei's external affairs.

${ }^{15}$ Azahari was of mixed Arab-Malay parentage, hence technically an alien, and ineligible to lead his party in legislative elections.

${ }^{16}$ A considerable literature on the formation of Malaya exists. Three of the briefer accounts are: Emily Sadka, "Malaysia: The Political Background," The Political Economy of Independent Malaya (Berkeley: U. of California Press, 1963); Gordon P. Means, "Malaysia - A New Federation in Southeast Asia," Pacific Affairs, 36 (Summer 1963); and the author's "The Formation of Malaysia," Current History (February 1964).
} 
drawn. If merger with Singapore were quickly arranged under joint auspices with PAP moderates, then the Malayan Alliance would presumably control the central government, and most importantly, internal security.

The delicate Malay-Chinese demographic balance in Malaya would be imperiled by absorption of overwhelmingly Chinese Singapore. If, however, the mixed populations of Borneo were included, Chinese preponderance would be forestalled and continued Malay governmental control insured, at least for a considerable time. All three units of British Bomeo were invited to adhere to the new state. The scheme plainly (and unjustifiably) assumed an identity of interests between peninsular Malays and the indigenous peoples in Borneo vis-à-vis the Chinese.

An important supplementary security consideration was involved. A "greater Malaysia," with its five constituent units enjoying the highest regional economic prosperity, would be a far more defensible entity against possible future encroachment by Communist China than three or four smaller, isolated states. The original proposal was almost casually enunciated and subsequently implemented in record time.

The original Bornean reaction was mixed, splitting largely along communal lines. The local Malays and Islamized indigenes quickly endorsed the Malaysian proposal. They supported a strong central government under Federation, Islam as the national religion, and Malay as the national language.

While a minority of the non-Muslim indigenes preferred to retain British colonial rule, the majority was willing to accept Malaysia, if certain safeguards for its various groups could be assured. The selection of Heads of State in Sarawak and Sabah, it was argued, should be restricted to indigenes, who would also be eligible for appointment as Head of the Federation. They were opposed to Islam as a state religion, wanted English to remain an official language in Borneo, and favored reserving state civil service posts for Borneans, as soon as they could be trained by British expatriates.

Most Bornean Chinese were decidedly cool to the Malaysian proposal and preferred the option of independent Bornean states or a Bornean federation. Their principal fear was that the Alliance's Malay political leaders in Kuala Lumpur would dominate subordinate Borneo and discriminate against the Chinese. Like the non-Muslim indigenes, they opposed Islam as a state religion and wanted English retained as an official language. While they were willing that indigenes be given special educational opportunities due to their backward position, the Chinese opposed constitutional status for such privileges. All three groups wanted the Bornean states granted control over their own immigration and favorably weighted representation in the Federal Parliament. ${ }^{17}$

Between 1961 and 1963 a common developmental pattern marked the emergence of unstable party systems in both Sarawak and Sabah. Its major characteristics were as follows:

\footnotetext{
${ }^{17}$ This spread of opinion was reported by the Cobbold Commission, comprised of British and Malayan representatives, that visited Borneo in 1962. Its report is also a useful source of information on the first political parties in Sarawak and Sabah. See Report of the Commission of Inquiry, North Borneo and Sarawak, Kuala Lumpur, 1962.
} 
1. The fundamentally communal character of party structures. Despite the multi-racial origins of several parties, the basic ethnic component of all parties was clearly identifiable by 1963 . In Sarawak the ethnic breakdown was as follows:

\section{Political Party}

Sarawak United People's Party (SUPP)

Sarawak Chinese Association (SGA)

Party Negara Sarawak (PANAS)

Barisan Ra'ayat Jati Sarawak (BARJASA)

Sarawak National Party (SNAP)

Party Pesaka Anak Sarawak (PAPAS)

Predominant Ethnic Component
Chinese
Chinese
Malay
Malay
Iban
Iban

A specific causation is ascertainable for the diminution in the multi-racial character which SUPP and PANAS in particular originally exemplified. The close link between SUPP's radical faction and the CCO, eventually carried to the extreme of collaboration in Indonesia's "confrontation" campaign against Malaysia in 1963, alienated an increasing number of SUPP's Iban supporters. The somewhat erratic policy shifts which the Datu Bandar intermittently imposed on PANAS were an important factor in driving a number of its original followers into new party formations. Increasingly PANAS became the voice of a single Malay faction.

An important causative factor in the formation of two separate Iban parties was the geographic division of the Iban community, each with its own traditional leaders. Ibans in the Second Division affiliated with SNAP, those in the Third Division comprised the bulk of PAPAS' support; each party apparently agreed to respect the other's base region.

The Chinese community was very unevenly divided. Most workers, smaller entrepreneurs, and younger Chinese between 17 and 24, many of whom had attended Chinese-medium schools, were attracted to SUPP. The much smaller SCA represented middle-class and upper-income Chinese businessmen and some of the older generation of Chinese; English-educated Chinese dominated its leadership.

The ethnic divisions in the somewhat less fragmented Sabah party system were as follows:

\begin{tabular}{ll}
\multicolumn{1}{c}{ Political Party } & Principal Ethnic Component \\
United National Kadazan Organization (UNKO) & Kadazan \\
United Sabah National Organization (USNO) & Bajau-Malay \\
Borneo Utara National Party (BUNAP) & Chinese \\
Pasok Momogun (PMP) & Murut-Kadazan
\end{tabular}

UNKO was consistently the most determinedly multi-racial of Sabahan parties in its policy statements and membership recruitment. Though basically a Kadazan party, UNKO attracted significant Sino-Kadazan support. Its organizer and principal leader, Donald Stephens, was himself an Anglo-Kadazan. In USNO the most important determinant of membership was adherence to the Muslim religion, especially among the Bajaus and the several Malay groups. While Pasok Momogun had Murut leadership, it drew substantial support from dissident Kadazans, who rejected UNKO; Muruts and Kadazans are ethnically related. Kadazans in the 
interior tended to support Pasok Momogun, those in the developed coastal areas, UNKO.

2. A very marked tendency for initially anti-Malaysia parties to shift at variable intervals to varying degrees of support for Malaysia. As already indicated, nonMuslim groups tended to be originally hostile or lukewarm to the Malaysian proposal; by 1963, SUPP was the only remaining, clearly anti-Malaysia party. A complex of factors account for this substantial movement of opinion.

The Malayan Government invited a large number of Bornean political leaders to Kuala Lumpur for briefing sessions and tours that featured impressive Rural Development projects, sponsored by the Alliance Government; it was made plain that if Borneo joined Malaysia, it could expect a similar program. UNKO's Stephens and SNAP's Iban leader, Stephen Kalong Ningkan, were among the visitors who soon adopted a pro-Malaysia position.

In 1962 a contingent of Bornean legislators joined British and Malayan representatives to form an Inter-Governmental Committee, chaired by Lord Lansdowne, to consider details of the pending Federation. Its recommendations removed most of the original objections raised by critics of Malaysia. ${ }^{18}$ Islam would be the national religion of Malaysia, but not of the Bornean states. Malay would be the national language; but for at least ten years English would remain an official language and thereafter until the Bornean legislatures decided otherwise. Bornean indigenes would receive preference in civil service positions. The Bornean states would retain a large degree of autonomy over education and immigration; in the Federal parliament their small populations would receive favorably weighted representation, Sarawak being granted 24 seats, Sabah $16 .{ }^{19}$

Finally the abortive Brunei revolt by Azahari's Party Ra'ayat in December 1962 consolidated Bornean support for Malaysia. ${ }^{20}$ The revolt, quelled by aid of British troops, raised the specter of a new era of Brunei domination. It also served as a catalytic agent, converting Indonesia's original acquiescence in the formation of Malaysia into its harsh policy of confrontation. Many Borneans now acquired a fresh appreciation for an umbrella of Anglo-Malayan military support that Malaysia would afford. ${ }^{21}$ Finally, as the formation of Malaysia appeared increasingly imminent, opportunistic calculations of future advantage led certain laggard groups, like Pasok Momogun and BUNAP in Sabah, belatedly to endorse the new Federation.

3. A fissiparous tendency seen in the formation of a number of splinter parties, partially counteracted by limited amalgamation. The fragmentation process was mainly noticeable in Sarawak, as BARJASA and PAPAS were formed by PANAS dissidents; to a much smaller extent, SCA was a splinter off SUPP. The PANAS

${ }^{18}$ Malaysia Report of the Inter-Governmental Committee 1962 (Federation of Malaya: Government Printer, 1963).

${ }^{19}$ More populous Singapore was granted only 15 seats in the Federal House, mainly due to the autonomy granted it in labor and education.

${ }^{20}$ An interesting account of the revolt is given in Arnold C. Brackman's Southeast Asia's Second Front: The Power Struggle in the Malay Archipelago (New York: Praeger, 1966), pp. 139ff. The revolt received considerable support in adjacent areas in Sarawak and a small area in Sabah.

${ }^{21}$ The Filipino claim to Sabah, vigorously advanced in 1963, had a similarly cohesive effect on pro-Malaysia parties in Sabah. 
splinter parties reflected a hardening in communal lines. A reverse fusion process was seen in the formation of BUNAP in Sabah, when the Democratic and United parties, both Chinese, combined. Here the Chinese realized that political division weakened their minority position.

4. Initial predominance of traditional leaders in new party organizations. In the rapid proliferation of essentially communal parties, established tribal leaders inevitably held key positions. Leading examples were the founder of PAPAS, Temenggong Jugah anak Barieng, and in Sabah, Pasak Momogun's O.K.K. Sundang. In Muslim parties there was a similar trend, the Datu Bandar in PANAS, and in Sabah the leader of USNO, Datu Mustapha bin Datu Harun, being examples. A contributing factor to the paucity of leadership alternatives was the considerable number of well-educated civil servants in both states, cut off by their status from party politics.

To the traditionalist norm there were noteworthy variations. With the extension of local government in the 1950's, new political reputations were established, as that of Ong Kee Hui in Sarawak. A few leaders arose from occupationally obscure origins, like SNAP's Ningkam, a former medical dresser. At the secondary tier of leadership an ambitious group of youthful leaders soon emerged, like UNKO's Peter J. Mojuntin and in Sarawak, BARJASA's Taib bin Mahmud and PAPAS's Penghulu Francis Umpau.

5. An assertion of nationalist claims by a number of indigenous parties, advanced in certain policy statements and the very names of several indigenous parties, as the Iban-dominated Sarawak National party and the Muslim United Sabah National Organization. Such claims assumed that a self-appointed indigenous group epitomized the whole social organism, its pre-eminence to be properly acknowlged by other ethnic communities, especially the alien Chinese. Their assertion stimulated the Chinese, particularly in Sabah, to counter-organization.

6. The formation of inter-racial Alliances on the Malayan pattern by the proMalaysia parties. ${ }^{22}$ In a racially fragmented society the utility of an interracial coalition to attenuate recurrent ethnic conflicts was apparent. In the Bornean Alliances, common commitment to Malaysia proved an indispensable integrative element. In Sarawak the Iban parties, SNAP and PAPAS, first formed a united front, subsequently joined by the two Malay parties, PANAS and BARJASA, and by SCA. In Sabah UNKO assumed leadership in a similar grouping with USNO, which BUNAP and PMP joined. A numerically insignificant Sabah Indian Con-

${ }^{22}$ The Malayan Alliance party (MAP), formed between 1952-55, had as its leading components, the United Malays National Organization (UMNO) and the Malayan Chinese Association (MCA), supported by the much smaller Malayan Indian Congress (MIG). Initially MAP was an electoral combination; since independence in 1957, it has constituted a fairly effective, moderately progressive Government. Its leading Malay members have been Prime Minister Rahman and his Deputy, Tun Razak; the able Tan Siew Sin, head of MCA, Minister of Finance.

MAP's essential purpose is to provide a workable mechanism for mediating and compromising opposing demands of its communal partners, usually by means of behindclosed-doors discussions. Despite persisting differences over the status of Chinese-medium education, MAP has functioned with considerable success, suffering only one major exodus by dissident Chinese. MAP, however, had a prolonged gestation period and assumed a governmental role only after the British had defeated the main thrust of the Communist insurgency. 
gress was also affiliated. The Malayan Alliance party (MAP) encouraged these pro-Malaysia formations, not only because hopefully they would enhance the new Federation's internal stability but also allow MAP to forge a pan-Malaysian Grand Alliance to facilitate control of its Bornean affiliates. The mainland MCA was especially aggressive in prodding Bornean Chinese to form counterpart organizations, apparently to the excessive degree in Sarawak of alienating a number of Chinese.

Even before the sequence of Council elections in Sarawak in 1963, the fragile character of its new Alliance was indicated. PANAS abruptly withdrew, partly in resentment against MAP's interference in Sarawak Alliance matters, and later established liaison with the anti-Malaysia SUPP to avoid being shut out of representation on Council Negri.

Several features of the pre-Malaysian elections require comment. ${ }^{23}$ Both Alliances scored impressive electoral victories, paving the way for Alliance coalition Governments with the advent of Malaysia. The elections confirmed the communal character of Bornean political parties with a striking correlation between ethnic percentages in certain districts and the electoral showing of the corresponding communal party. The indirect system resulted in a certain distortion in the electorate's preferences expressed at the local level. For example, in Sarawak, SUPP received 24.5 per cent of the District Council vote, but held only 5 of the 36 elective seats in the Council Negri; even this allocation was due to its makeshift alliance with PANAS. In both District and Divisional Electoral Colleges a considerable amount of inter-party bargaining was necessary to determine distribution of legislative seats. In Sabah, the Muslim USNO emerged as the strongest single party in the Alliance occurred, most frequently between UNKO and Pasok Momogun. This indicated a limited degree of consensus within its Alliance.

From these early elections, the Sarawak Alliance appeared chiefly as an Iban party with limited Malay support. The dissident PANAS made a considerably better showing than its Malay competitor, BARJASA. The SCA proved a negligible element, with the Opposition SUPP winning overwhelming Chinese support. In Sabah, the Muslim USNO emerged as the strongest single party in the Alliance but with UNKO in a strong second position, subsequently improved by its merger in 1964 with Pasok Momogun, which united the Kadazan community.

\section{Patterns of Gabinet Instability (1963-66)}

In contrast to their Malayan model, the governing Alliances in Sarawak and Sabah proved unstable, crisis-ridden coalitions. Between Malaysia Day in September 1963 and mid-1966, both suffered two major crises, ending in the dislodgment of their respective Chief Ministers, Ningkan in Sarawak, Stephens in Sabah. In both states the crises resulted in a major shift in the relative power positions of each coalition's members, with certain parties of the non-Muslim indigenes, SNAP in

\footnotetext{
${ }^{23}$ These have been analyzed in some detail in Robert O. Tilman's "Elections in Sarawak," Asian Survey (October 1963), and H. R. Glick, "The Chinese Community in Sabah and the 1963 Election," Asian Survey (March 1965); they have been placed in a wider context in Tilman's "The Alliance Pattern in Malaysian Politics: Bornean Variations on a Theme," South Atlantic Quarterly (Winter 1964).
} 
Sarawak and UPKO in Sabah, ${ }^{24}$ subjected to a considerable diminution in influence. In Sarawak a so-called "Native Alliance" between the militantly Malay BARJASA and the communally minded younger leadership in the second Iban party, PAPAS, challenged SNAP, with its multi-racial outlook, and its leader, Ningkan, with his suspiciously close links to British expatriate civil servants. Typically, PANAS did not play a consistent role in the Sarawak disputes, first allying with the "nativists," later siding with SNAP. In Sabah the Chinese party, playing a kind of balancer role, emerged as an immediate beneficiary of the basic rivalry between the Kadazan UPKO and Muslim USNO, at the end of 1964 when Peter Lo replaced Stephens as Chief Minister. ${ }^{25}$

In addition to inducing internal power realignments, the Bornean crises had these noteworthy characteristics:

1. An apparent predominance of party organs over Government bodies in their respective crisis roles, without, however, a sharp differentiation. With minor deviations the usual developmental sequence in a given crisis was as follows: initiation of a controversial Government policy or appointment, which precipitated the dispute; ensuing inter-party haggling, usually carried on outside the parliamentary arena; the threat of parliamentary motions of non-confidence against the challenged Chief Minister; the use of party bodies, both local and federal, in behindclosed-doors attempts to mediate the dispute and prevent dissolution of the Alliance; and either deferring a decisive resolution of the conflict by a relatively minor Cabinet rearrangement, or alternatively, registering an apparently final settlement by party ratification of a major Cabinet reshuffle.

2. Complication of the substantive disputes by the personality factor. The exacerbating role of jarring personalities was especially marked in Sabah, where the Ghief Minister, UPKO's Stephens, and the Head of State, the USNO leader, Tun Mustapha, strongly disagreed on their respective constitutional roles. In Sarawak a policy dispute over proposed land legislation was utilized and perhaps provoked by several leaders to support their thrust for political advancement, as notably in the case of BARJASA's Taib, who, it was widely believed, aspired to succeed Ningkan as Chief Minister.

3. Reliance on UMNO leaders in the mainland MAP to play the decisive mediatory role, underscoring the clearly subordinate position of the Bornean Alliances. Frequent shuttlings between the Bornean capitals and Kuala Lumpur characterized each crisis, with the two principal UMNO leaders, Rahman and Razak, sometimes holding separate audiences for the various Bornean factions. While both UMNO leaders repeatedly professed their neutrality between opposing sides and primary concern with preserving Alliance unity, UMNO appeared at times to play

\footnotetext{
${ }^{24}$ After several months of private negotiations between UNKO and PM, their merger as the United Pasokmomogun Kadazan Organization (UPKO) was announced in April, 1964. Stephens and Sundang served temporarily as joint chairmen.

${ }^{25}$ Sabah's pre-Malaysian Chinese party, BUNAP, later changed its name to the Sabah National party (SANAP). In early 1965 the proposal to merge SANAP with the Sabah Chinese Association, hitherto essentially a social welfare organization, provoked criticism from some Chinese, who opposed the formation of a single Chinese political organization. Chief Minister Lo was subsequently chosen chairman of the reorganized Sabah Chinese Association (SCA). This new party reinforced the pervasive communalism in Sabah politics.
} 
a protective role on behalf of its Bornean counterparts, BARJASA and to a lesser extent PANAS in Sarawak, USNO in Sabah. ${ }^{26}$ The relative decline of the nonMuslim indigenous parties provides partial circumstantial evidence. In both states the challenged indigene Chief Ministers, Ningkan in Sarawak and Stephens in Sabah, adopted states'-rights postures, resentful of UMNO's intervention as prejudicial to their own parties' interests. Ningkan in particular posited the alternative of having the State Alliance's Council, as an autonomous body, settle its own internal disputes. With heavy reliance by the Bornean states on the central Government for military defense and financial assistance for economic development, the interest of federal party bodies in Bornean matters could scarcely be ignored.

Further evidence of UMNO's involvement in Bornean politics was seen in the pressure it exerted on Muslim parties there to convert themselves into UMNO branches, further strengthening the Malay component in MAP. In turn the power of the UMNO-dominated Gentral Government would be enhanced. A deterrent to fusion of Muslim parties was the multi-racial professions of Bornean parties, as by USNO in Sabah, partly based on their desire for a wide local base. A troublesome prerequisite in Sarawak was the necessity of a prior merger by PANAS and BARJASA, intermittently reported as imminent, but consummated only in 1967.

Despite a marked parallelism in the evolving Bornean Alliances, there were distinguishing features in their respective political environments. While both states from early 1963 were directly threatened by Indonesian armed incursions, Sarawak bore the brunt of border raids. A significant number of young Sarawakian Chinese under $\mathrm{CCO}$ discipline crossed into Indonesian Kalimantan for instruction in guerrilla tactics, some of these subsequently leading raiding parties back into Sarawak settlements personally familiar to them. ${ }^{27}$ Sabah's less radical Chinese community spared its Alliance Government a similarly acute problem of internal subversion.

Unlike Sabah, the Sarawak Alliance Government was confronted with a formidable parliamentary Opposition, provided chiefly by SUPP and to a lesser extent by PANAS. Its effectiveness was chiefly seen in the searching questions SUPP legislators raised in Council Negri debates and SUPP's publicizing of the Alliance's recurrent internal frictions, subjecting them to a critical running commentary. Internal fissures in SUPP were in turn, however, exploited by the Government. Attention was forcefully drawn to certain SUPP branches allegedly under CGO discipline, although the effects of these attacks were blunted by declarations of loyalty to the new Federation by SUPP's dominant moderate leaders following Malaysia Day in 1963. Finally, the emergency powers of the central Government were in cooperation with the Sarawak Government employed to proscribe certain SUPP branches and prohibit large public meetings of a political character.

In Sabah there was no formal Opposition. In its stead, worsening frictions between UPKO and USNO created an unsystematic, de facto intra-Alliance Oppo-

${ }^{26}$ In 1963 UMNO had insisted on Muslim Heads of State in Borneo, if non-Muslim indigenes served as Chief Ministers.

${ }^{27}$ Imprecise, but probably conservative official estimates held that approximately a thousand Sarawakian Chinese youth had defected since Malaysia Day. The loyalty to Malaysia of a large number of Chinese farmers in the First Division bordering Kalimantan was dubious in the extreme. 
sition. When UPKO's Stephens was Chief Minister, UPKO was subjected to a restricted cross-fire from USNO, these positions being reversed after Stephens was relieved in 1964. An important policy divergence between UPKO and USNO was the timing of the introduction of direct elections. Each of the two parties tended to shift its position on this issue, depending in part on calculations of its relative electoral strength at a given time. An important contributing factor to intra-Alliance tensions was the tendency for UPKO and USNO to engage periodically in raiding each other's members.

Sabah's two successive Cabinet crises preceded those of Sarawak. ${ }^{28}$ Fresh elections for an enlarged Legislative Assembly in the spring of 1964 had reinforced USNO's position as the leading Alliance party controlling the largest number of legislative seats. USNO then challenged UPKO's retention of the key post of Chief Minister, unleashing a power struggle with UPKO. In June a compromise settlement was arranged in Kuala Lumpur under the aegis of Tunku Abdul Rahman. Sabah's original Cabinet of eight members was enlarged to ten, the majority of its old members receiving new Cabinet assignments. A non-party man (but with UPKO sympathies) was appointed Minister of Natural Resources, the able Attorney-General, Thomas Jayasuriya. Stephens was allowed to continue as Chief Minister. USNO was temporarily placated with the appointment of Harris bin Mohammed Salleh to the newly created post of Deputy Chief Minister. A special feature of this settlement was the mutual pledge taken by the indigenous parties and SANAP that in the future they would confine their membership recruitment to their respective ethnic groups; it proved short-lived in practice.

Within six months the Sabah Alliance was confronted with a considerably graver crisis. Its precipitant was a constitutional hassle with communal overtones. Tun Mustapha as Head of State refused to take Chief Minister Stephens' advice concerning the appointment of a Kadazan, John Dusing, to the important post of State Secretary, previously held by an expatriate. To UPKO, Tun Mustapha's presumed disinterestedness as an apolitical Head of State was suspect, since he remained deeply involved in USNO affairs. In turn USNO leaders charged that Stephens had failed to consult his ministerial colleagues on the Dusing appointment, an obvious handicap for a smoothly functioning coalition Cabinet.

This time a more ambitious mediatory effort was required. In the first discussions with Tunku Abdul Rahman, initiated by the Sabah Alliance parties, it was clear that frictions between Mustapha and Stephens had reached the stage that virtually necessitated the latter's replacement. The Tunku sponsored a sweeping reorganization of the Sabah Cabinet. Peter Lo, representing SANAP and presently serving in the Federal Cabinet, would return to Sabah as its new Chief Minister, and Stephens would take over his Federal position; a second UPKO leader, Sundang, would be appointed Deputy Chief Minister. Stephens, unwilling for UPKO to lose the post of Chief Minister, alternatively proposed that Sundang replace him as Chief Minister. The discussions in Kuala Lumpur temporarily broke down.

Meanwhile USNO leaders in Jesselton, with SANAP's support threatened to bring a motion of no-confidence against Stephens in the Sabah legislature, which

\footnotetext{
${ }^{28}$ The details of the succession of cabinet crises in Borneo were obtained from interviews with politically informed persons in Sabah and Sarawak and newspaper files.
} 
if passed, would require a Cabinet reorganization. UPKO retaliated by threatening a similar motion against the Head of State. An ancillary mediatory effort was launched by a SNAP delegation from Sarawak, led by Ningkan, but a final settlement incorporating the Tunku's originally proposed changes had to be agreed upon in Kuala Lumpur. Lo was named Chief Minister, Stephens given a consolatory Federal Ministry. The crucial factor in resolving the December crisis, distinguishing it from the June dispute, had been SANAP's willingness to abandon its earlier neutrality between USNO and UPKO, and in a deadlock situation join informally with USNO to depose the UPKO Ghief Minister. Subsequently UPKO leaders publicly expressed resentment over their Alliance partners' "ganging up" against them. Obviously the second crisis had been settled only by patching up the USNOUPKO quarrel without insuring a genuine unity in the Sabah Alliance.

The initial Cabinet crisis of the Sarawak Alliance in May 1965 ostensibly arose over the Government's proposed land reform legislation. Actually it involved a complicated maneuver by a new party alignment to reduce, if not eliminate the influence of the professedly multi-racial SNAP and SCA, the Chinese member of the Alliance; in personal terms, the intent was to replace Ningkan as Chief Minister. The new grouping, subsequently labeled the "Native Alliance," comprised one Iban member, PAPAS, and two Malay parties, BARJASA and PANAS, the latter having withdrawn from the Alliance in 1963.

In the formation of the Native Alliance the personal equation was extremely important. In BARJASA the two key leaders were Taib bin Mahmud, its secretarygeneral and also a member of the Sarawak Cabinet, and his uncle, Abdul Rahman Ya'akub, Federal Minister of Land and Mines, whom some observers believed was the main instigator of a revamped Alliance. A group of "Young Turks" in PAPAS, all members of their Party Executive, Penghulus Jinggut and Francis Umpau, Jonathan Banggau and Thomas Kana, enlisted the wavering support of their senior party leader and chairman, the aging but still dynamic Temenggong Jugah, who was simultaneously chairman of the Sarawak Alliance and Federal Minister for Sarawak Affairs. The PANAS leader, Abang Othman, was chiefly influential in securing his party's adherence to the new Alliance.

Under the British colonial administration, the Natives had enjoyed certain privileges in land ownership and occupation, with the alien Ghinese virtually excluded from settling whole areas. In early 1964 Chief Minister Ningkan had enunciated a new land policy, which included a clarification in the legal titles of Native landholders, many of whom held land under customary rights, and opening up a certain amount of new land to Chinese farmers. The Government's aim in Ningkan's words was "to satisfy all sections of the community." 29 Nearly a year was required for intra-Alliance consultations and drafting of complex new Land Bills, implementing this multi-racial approach. But their introduction in the Council Negri provoked an outburst of criticism by indigenes, some of whom feared that many wealthy Chinese towkays would immediately buy up large sections of the land which would thus be made available, and in this manner gain and perpetuate a stranglehold on the rural economy. Under heavy pressure the Government with-

29 "Sarawak by the Week," No. 12/64. 
drew its Land Bills, which did not, however, prevent a worsening in the mounting Alliance crisis. ${ }^{30}$

The ensuing tactical moves of Ningkan's challengers and countermoves made by the Chief Minister with his Iban and Chinese supporters developed in the following sequence: (1) BARJASA announced its withdrawal from the Alliance, apparently the first step in making Ningkan's position insupportable; (2) the Ghief Minister quickly sacked BARJASA's two Cabinet members, including Taib, and attempted to undercut the new-found unity of the Malay parties, by inviting PANAS to rejoin the Government; (3) PANAS refused to accept Ningkan's gambit, maintaining that its entering the Cabinet would undermine Malay unity and frustrate the incipient Native Alliance; (4) a series of inconclusive consultations were held in Kuala Lumpur, led by Tun Razak, in which Ya'akub and his "nativist" colleagues in Sarawak initially played an exclusive role, but to which it was anticipated Ningkan would soon be summoned; (5) Ningkan shrewdly countered by refusing to go to the Federal capital, where UMNO influence was dominant, combined with his exploitation of Jugah's desire to preserve Iban unity, even at the cost of scrapping the Native Alliance, to which Jugah was ambiguously committed.

The turning point of the crisis, forestalling the imminent disruption of the Alliance, was a Ningkan-Jugah meeting in early June, held in Sibu, the Third Division stronghold of PAPAS. Two imprecisely calculable influences accounted for Jugah's shift away from the Native Alliance: his attachment to Iban solidarity and the counsel of the SCA leadership, with whom Jugah had close ties.

The multiple formula Ningkan and Jugah devised to salvage the Alliance was as follows: BARJASA's re-entry into the Cabinet; PANA's renewed adherence to the Alliance, sealed by Abang Othman's admission to the Cabinet; two new PAPAS members in the Cabinet, including the rebel Umpau; and Ningkan's retention of his post as Chief Minister. ${ }^{31}$ The Native Alliance was unceremoniously dropped, enabling the Alliance to maintain its multi-racial character. Finally, Ningkan was unable to resist underscoring his triumph by requiring BARJASA leaders to pledge loyalty to him and the Cabinet, and in the subsequently issued order of Cabinet precedence a presumably chastised Taib was relegated to last place.

A strikingly similar crisis occurred a year later with a slightly different constellation of forces but a radically different result. In June 1966, Ningkan revealed that a rebel group in the Sarawak Alliance was "plotting to topple the Government" with the help of "some people from outside Sarawak," an allusion to Ya'akub and his UMNO colleagues in Kuala Lumpur.." "To prevent trouble," the Chief Minister once again sacked the BARJASA Cabinet member (and alleged co-conspirator), Taib.

Three significant differences were apparent between the 1966 crisis and its predecessor: (1) PANAS this time supported the challenged Ningkan; (2) the

\footnotetext{
${ }^{30}$ From this sequence it was inferentially argued by critics of the Native Alliance that the Land Bills were largely a ploy in what was essentially a power play by the projected Malay-Iban combination.

${ }^{31}$ "Sarawak by the Week," No. 25/65.

${ }^{32}$ The Straits Budget, June 22, 1966, p. 5.
} 
PAPAS-BARJASA combination held firm, offsetting a lack of unity between the Malay parties; and (3) emphatic Federal intervention, led by Tunku Rahman and Tun Razak, proved decisive in quickly dislodging Ningkan as Chief Minister.

A curious maneuver brought Ningkan down. After threatening to introduce a motion of no-confidence against the Chief Minister in the Council Negri, a twenty-man PAPAS-BARJASA delegation, constituting a controlling Council majority, abruptly departed for Kuala Lumpur. There they insisted that the Tunku, as head of the National Council of the Malaysian Alliance party, take steps to remove Ningkan. Ningkan vainly argued that only the Council Negri in Sarawak could by a negative confidence vote constitutionally oust him. These protestations were, however, brushed aside, as the Tunku shortly announced that the Alliance Council in the Federal capital had selected another Iban, Penghulu Tawi Sli, a hitherto obscure chairman of a local council, to replace Ningkan. Jugah's pointed desertion of Ningkan, insuring united PAPAS action under the "Young Turks," doomed a counter-strategy based either on Iban solidarity or insistence on autonomous state action.

The future of the Bornean Alliances was highly problematical. Between 1963 66 the critical national emergency, with Borneo as the major war front, stimulated a certain cohesiveness in these coalitions. With the end of Indonesian confrontation and departure of the British defense troops, the stark necessity of maintaining a modicum of national unity was less compelling. The pending direct elections in Sabah would define a new power ratio between UPKO and USNO and probably determine the fate of the Sabah Alliance. ${ }^{33}$ In Sarawak the staying power of an Iban-Malay combination was the crucial factor in maintaining its Alliance. In both states the first three years had established the primacy of the Federal Alliance leadership in making basic personnel decisions for the embattled Bornean Alliances, with a concomitant decline in the relative power of non-Muslim indigenous political groupings, more marked thus far in Sabah than Sarawak. Indeed a trend toward a Malaysianization of the Bornean Alliances appeared the most likely future development. But the racially fragmented societies in Borneo and the inevitable expanding influence of the Bornean Chinese argued against the viability of crudely UMNO-centered political structures in either Sarawak or Sabah.

\footnotetext{
${ }^{33}$ Subsequent to the completion of this article, direct elections for the Sabah Legislative Assembly were held in April 1967. Since USNO and UPKO could not agree in advance in the allocation of seats between the two parties, they conducted what were euphemistically described as "friendly" contests in 21 out of 32 constituencies. USNO won 14 seats, UPKO 12. The SCA, with whom USNO had collaborated during the campaign, held 5 seats, an Independent winning the remaining one. After so bitter a campaign, USNO and UPKO proved unable to form a new state Cabinet, and UPKO formally assumed the role of Opposition party. Attempts by Federal Alliance leaders to restore Alliance unity in Sabah have thus far failed.
} 